\title{
HIST1H3B NM_003537.3:C.83A>T
}

National Cancer Institute

\section{Source}

National Cancer Institute. HIST1H3B NM 003537.3:C.83A>T. NCI Thesaurus. Code

C154311.

A nucleotide substitution at position 83 of the coding sequence of the HIST1H3B gene where adenine has been mutated to thymine. 